\title{
Sediminitomix flava gen. nov., sp. nov., of the phylum Bacteroidetes, isolated from marine sediment
}

\author{
Shams Tabrez Khan, Yasuyoshi Nakagawa and Shigeaki Harayama \\ Biological Resource Center (NBRC), National Institute of Technology and Evaluation (NITE), \\ 2-5-8 Kazusa-kamatari, Kisarazu, Chiba 292-0818, Japan
}

Correspondence

Shams Tabrez Khan

shams-tabrez-khan@nite.go.jp
The phylum Bacteroidetes consists of three large classes, Bacteroidetes, Flavobacteria and 'Sphingobacteria' each comprising of only one order (Bernardet et al., 2002). They are widely distributed in terrestrial and marine environments and are dominant populations in gastrointestinal flora (Shewan \& McMeekin, 1983; Leser et al., 2002; Bäckhed et al., 2005). Since 2003, the number of recognized genera in the phylum Bacteroidetes has increased exponentially, suggesting that the phylum contains many as yet undiscovered members.

In this paper, the isolation of a marine bacterium belonging to the family 'Flammeovirgaceae' is reported. The family 'Flammeovirgaceae' contains four genera (Garrity \& Holt, 2001) namely Flammeovirga (Takahashi et al., 2006; Nakagawa et al., 1997), Persicobacter (Nakagawa et al., 1997), Flexithrix (Lewin, 1970) and Thermonema (Hudson et al., 1989). With the exception of the genus Thermonema which includes thermophilic bacteria, the other genera of the family are mesophilic and share very similar characteristics.

Strain Mok- $1-85^{\mathrm{T}}$ was obtained from a marine sediment sample collected from Okinawa Island, Japan. The sediment sample was serially diluted in sterile artificial seawater (Naigai Chemicals) and an aliquot of each dilution was spread on half-strength marine agar $[19 \mathrm{~g}$ Bacto Marine Broth 2216 (Difco), $17 \mathrm{~g}$ artificial seawater and $15 \mathrm{~g}$ agar dissolved in 11 distilled water; HSMA]. The HSMA plates

The GenBank/EMBL/DDBJ accession no. for the 16S rRNA gene sequence of Sediminitomix flava strain Mok- $1-85^{\top}$ is AB255370. were incubated at $30{ }^{\circ} \mathrm{C}$ for 7 days. Strain Mok-1- $85^{\mathrm{T}}$ formed large irregular orange-coloured colonies on HSMA plates after 3 days of incubation. The strain was preserved at $-80{ }^{\circ} \mathrm{C}$ in artificial seawater supplemented with $20 \%$ glycerol $(\mathrm{v} / \mathrm{v})$.

Prepman Ultra (Applied Biosystems) was used to prepare a DNA template for 16S rRNA gene amplification. PCRmediated amplification of the partial sequence of a $16 \mathrm{~S}$ rRNA gene corresponding to positions 8-1492 of the Escherichia coli 16S rRNA gene sequence (Brosius et al., 1978) was carried out using the universal pair of primers 27f and 1492r according to the protocol of Hiraishi et al. (1994). Purified PCR product was sequenced directly using an ABI Big Dye Terminator Cycle Sequence kit (version 3.1) and an ABI PRISM 3100 Genetic Analyzer (Applied Biosystems). An almost complete $16 \mathrm{~S}$ rRNA gene sequence (1415 bp) was obtained. Using the sequence data, a BLAST search (Altschul et al., 1990) of the DNA DataBank of Japan (DDBJ) was performed to detect the closest relatives of strain Mok-1-85 ${ }^{\mathrm{T}}$. Lishizhenia caseinilytica (GenBank accession no. AB176674) was found to be the closest relative with a $16 \mathrm{~S}$ rRNA gene sequence similarity of $86 \%$. Related sequences were downloaded from DDBJ and aligned with the sequence of strain Mok-1 $-85^{\mathrm{T}}$ using the CLUSTAL_X software package (Thompson et al., 1997). Evolutionary trees were inferred using the neighbour-joining (Saitou \& Nei, 1987) and maximum-parsimony (Swofford, 2000) methods and the robustness of the phyletic lines was evaluated by using bootstrap analyses (Felsenstein, 1985) with 1000 replicates. The branching patterns of the two 


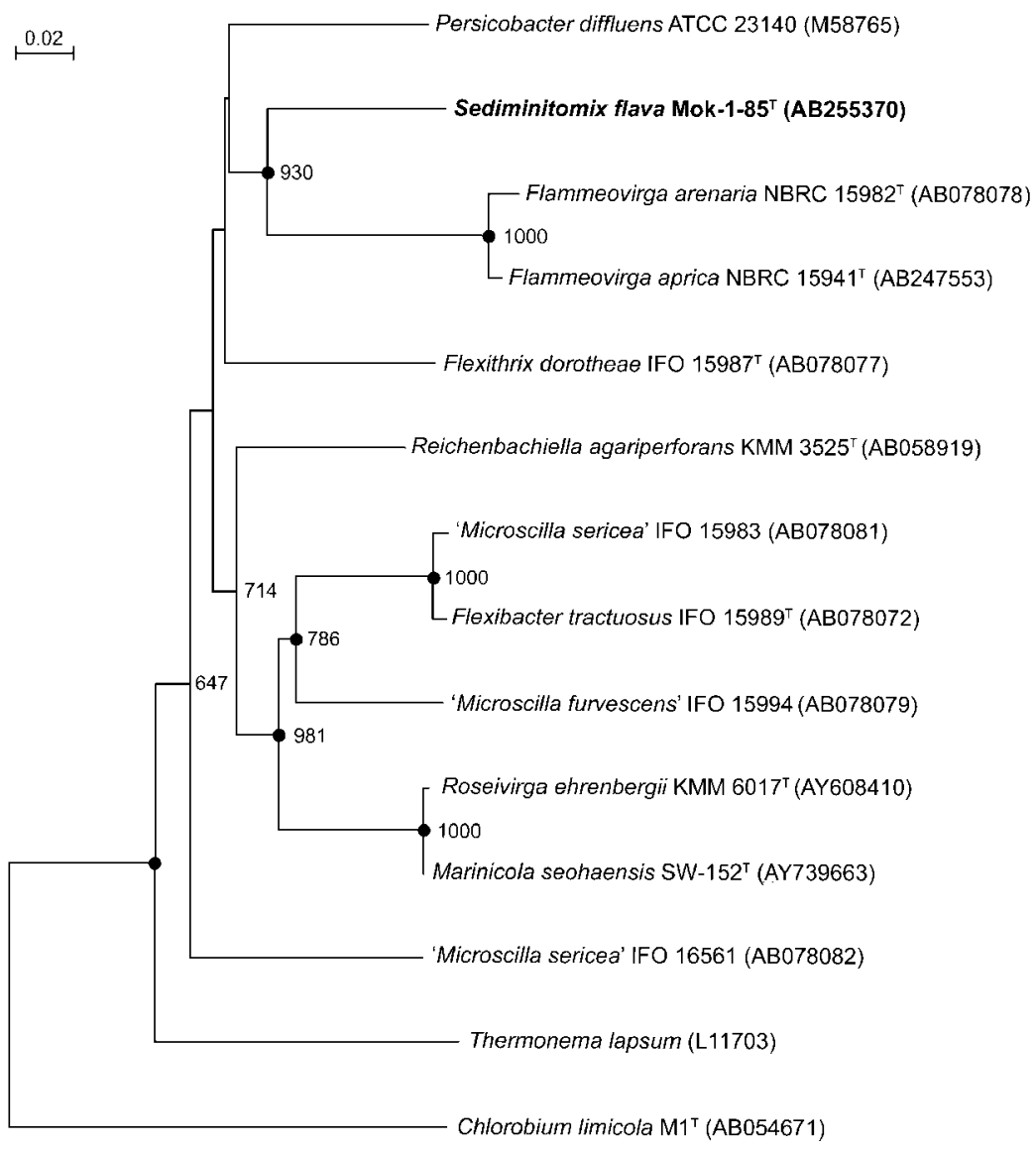

Fig. 1. Neighbour-joining phylogenetic tree of Sediminitomix flava sp. nov. Mok-1-85 ${ }^{\top}$ and related genera based on 16S rRNA gene sequence comparisons. Bootstrap values are indicated at the branches from 1000 replications. Only significant bootstrap values $(>500)$ are shown. The sequence of Chlorobium limicola $\mathrm{M}^{\top}{ }^{\top}$ was used as an outgroup. GenBank accession numbers are given in parentheses. Closed circles at the nodes represent branches that were also recovered in maximum-parsimony analysis. Bar, 0.02 $K_{\text {nuc }}$.

trees obtained by the neighbour-joining (Fig. 1) and maximum-parsimony (data not shown) methods were slightly different from each other. However, the novel isolate formed a cluster, supported by high bootstrap values, with members of the genus Flammeovirga in both trees (Fig. 1). Pairwise 16S rRNA gene similarities with other related genera were also checked. Strain Mok-1-85 shared $\leqslant 86 \%$ sequence similarity with other related genera.

Exponentially growing cells of strain Mok- $1-85^{\mathrm{T}}$ taken from HSMA plates after 2-3 days of incubation at $30{ }^{\circ} \mathrm{C}$ were used for the following tests unless specified otherwise. Cell morphology was observed under a light microscope equipped with a digital camera (CX41LF; Olympus). Cells were $0.5-0.7 \mu \mathrm{m}$ in width and $10-35 \mu \mathrm{m}$ in length. Gliding motility was checked on HSMA plates and by the hanging drop method described by Perry (1973) under a $\times 1000$ oil immersion objective. No gliding motility was observed on the HSMA plates or by the hanging drop method. The presence of flexirubin-type pigments was checked by the bathochromic shift test (Fautz \& Reichenbach, 1980) with $20 \%(\mathrm{w} / \mathrm{v}) \mathrm{KOH}$. Flexirubin-type pigments were absent. Extracts of cells for the carotenoid analysis were prepared as described by Schmidt et al. (1994) and the absorption spectrum (260-700 nm) was recorded using a UV-visible spectrophotometer (UV-1650 PC; Shimadzu).
The absorption spectrum obtained for strain Mok-1-85 was similar to that of Flammeovirga aprica NBRC $15941^{\mathrm{T}}$, indicating the presence of saproxanthin (Takahashi et al., 2006). The production of oxygen bubbles by the cells when mixed with $3 \%(\mathrm{v} / \mathrm{v}) \mathrm{H}_{2} \mathrm{O}_{2}$ on a glass slide was examined to check for the presence of catalase. The presence of oxidase activity was judged by the development of blue colour when cells suspended in sterile water were spotted on to a cytochrome oxidase strip (Nissui Pharmaceuticals). Strain Mok-1 $-85^{\mathrm{T}}$ tested positive for both catalase and oxidase activities.

Tolerance to high concentrations of $\mathrm{NaCl}$ was checked by growing the novel strain in half-strength marine broth (HSMB) supplemented with 4, 5, 6, 7, 8, 9 and $10 \%(\mathrm{w} / \mathrm{v})$ $\mathrm{NaCl}$. Growth on one-fifth-strength Luria-Bertani (LB) medium $[2 \mathrm{~g}$ Bacto tryptone (Difco) and $1 \mathrm{~g}$ Bacto yeast extract (Difco) in 11 water] supplemented with $0,1,2$ and $3 \%(\mathrm{w} / \mathrm{v}) \mathrm{NaCl}$ was also checked. The novel strain was able to grow on one-fifth-strength LB containing 2 and $3 \%$ (w/v) $\mathrm{NaCl}$ and in $\mathrm{HSMB}$ containing $4 \%(\mathrm{w} / \mathrm{v}) \mathrm{NaCl}$. However, no growth was observed in one-fifth-strength LB with $0 \% \mathrm{NaCl}$ or in $\mathrm{HSMB}$ supplemented with $6,7,8,9$ and $10 \%(\mathrm{w} / \mathrm{v}) \mathrm{NaCl}$. Weak growth was observed in HSMB with $5 \%(\mathrm{w} / \mathrm{v}) \mathrm{NaCl}$ and in one-fifth-strength $\mathrm{LB}$ with $1 \%(\mathrm{w} / \mathrm{v}) \mathrm{NaCl}$. The ability of strain Mok- $1-85^{\mathrm{T}}$ to grow at different temperatures was checked on HSMA plates 
incubated at $4,10,15,20,25,30,37,40$ and $42{ }^{\circ} \mathrm{C}$. Strain Mok- $1-85^{\mathrm{T}}$ was able to grow at $15,20,25,30,37$ and $40{ }^{\circ} \mathrm{C}$ and optimal growth took place at $25-30{ }^{\circ} \mathrm{C}$. No growth was observed on HSMA plates incubated at 4,10 or $42{ }^{\circ} \mathrm{C}$.

The degradation of cellulose was tested by placing cellulose paper strips (Whatman No. 1 filter paper) in cultures in one-fifth-strength LBM medium (one-fifth-strength LB prepared with artificial seawater). To test the degradation of carboxymethylcellulose (CM-cellulose), using an inoculating needle, the cells were stabbed deeply into one-fifthstrength LBM solidified with $3 \%(\mathrm{w} / \mathrm{v})$ CM-cellulose (high viscosity; Sigma). The degradation of agar and carrageenan (Sigma, type I) was assessed on plates of HSMB solidified with $1.5 \%(\mathrm{w} / \mathrm{v})$ of either of the polymers. The abilities of the novel strain to degrade starch, chitin, DNA, gelatin, Tweens 20, 40 and 80 and alginic acid and to produce $\mathrm{H}_{2} \mathrm{~S}$ were tested according to the protocols of Lewin \& Lounsbery (1969), Smibert \& Krieg (1981) and Cowan \& Steel (1993). Casein degradation was tested on casein plates [one fifth-strength LBM medium supplemented with $1.2 \%$ $(\mathrm{w} / \mathrm{v})$ casein and solidified with $1.5 \%(\mathrm{w} / \mathrm{v})$ agar]. The ability to grow on $1 \%(\mathrm{w} / \mathrm{v})$ peptone and tryptic soya agar (TSA) prepared with artificial seawater was tested on plates solidified with $1.5 \%(\mathrm{w} / \mathrm{v})$ agar. The survival of cells after treatment at $55{ }^{\circ} \mathrm{C}$ for $10 \mathrm{~min}$ was tested using cells suspended in sterile artificial seawater. The oxidation or fermentation of glucose (O/F test; Hugh \& Leifson, 1953) was checked by using O/F basal medium (Eiken Kizai) prepared with the artificial seawater. The reduction of nitrate and nitrite, the production of indole from tryptophan, the production of acids from glucose and the activities of urease, $\beta$-galactosidase and $\beta$-glucosidase were checked using API 20 NE strips (bioMérieux) according to the manufacturer's instructions, except that the cells were suspended in artificial seawater. Cells suspended in artificial seawater were also used to test the production of acids from various carbon sources (API 50CH strips; bioMérieux) and the activities of several enzymes (API ZYM strips; bioMérieux). The results of these phenotypic analyses are given in the genus and species descriptions and in Table 1.

The protocol of Minamisawa (1990) was used for the preparation of genomic DNA and the $\mathrm{G}+\mathrm{C}$ content was determined using the standard HPLC method of Mesbah et al. (1989). The $\mathrm{G}+\mathrm{C}$ content of the novel strain was $38 \mathrm{~mol} \%$. For the fatty acid analysis, strain Mok $-1-85^{\mathrm{T}}$ was grown on marine agar plates at $25{ }^{\circ} \mathrm{C}$ for $24-36 \mathrm{~h}$. The standard protocol of the Microbial Identification System (Microbial ID) was used for the preparation and analysis of fatty acid methyl esters. The predominant fatty acids of this organism were iso- $\mathrm{C}_{15: 0}, \mathrm{C}_{16: 1} \omega 5 c$ and $\mathrm{C}_{16: 0} 3-\mathrm{OH}$. Two of the three predominant fatty acids (iso- $\mathrm{C}_{15: 0}$ and $\mathrm{C}_{16: 0}$ $3-\mathrm{OH}$ ) were also found as the major fatty acids in members of the genus Flammeovirga (Takahashi et al., 2006), the closest phylogenetic neighbour to the novel strain. However the fatty acid profile of the novel strain was different from that of members of the genus Flammeovirga (Tables 1,2). The protocol of Nakagawa \& Yamasato (1993) was used for

Table 1. Characteristics that differentiate members of the genus Sediminitomix gen. nov. from related genera

Taxa: 1, Sediminitomix gen. nov.; 2, Flammeovirga (data from Takahashi et al., 2006); 3, Persicobacter (Nakagawa et al., 1997; Reichenbach, 1989); 4, Flexithrix (Lewin, 1970). +, Positive; -, negative; v, variable; NA, not available.

\begin{tabular}{|c|c|c|c|c|}
\hline Characteristic & 1 & 2 & 3 & 4 \\
\hline \multicolumn{5}{|l|}{ Pigment: } \\
\hline Colony colour & Orange & Orange reddish & Pink to orange & Golden yellow \\
\hline Gliding motility & - & + & + & + \\
\hline Length $(\mu \mathrm{m})$ & $10-35$ & $1.7-96$ & $4-30$ & $5-15^{\star}$ \\
\hline \multicolumn{5}{|l|}{ Degradation of: } \\
\hline Alginic acid & + & + & + & - \\
\hline Gelatin & + & $\mathrm{V}$ & + & - \\
\hline Starch & + & + & + & - \\
\hline $\mathrm{H}_{2} \mathrm{~S}$ production & + & + & - & - \\
\hline Major fatty acids & $\begin{array}{l}\text { iso- } \mathrm{C}_{15: 0}, \mathrm{C}_{16: 1} \omega 5 c \\
\text { and } \mathrm{C}_{16: 0} 3-\mathrm{OH}\end{array}$ & $\begin{array}{l}\text { iso- } \mathrm{C}_{15: 0}, \mathrm{C}_{20: 4} \omega 6 c, 9 c \\
12 c, 15 c \text { and } \mathrm{C}_{16: 0} 3-\mathrm{OH}\end{array}$ & NA & NA \\
\hline DNA G $+C$ content $(\mathrm{mol} \%)$ & 38 & $31-36$ & $40-42$ & 37 \\
\hline
\end{tabular}

${ }^{\star}$ Cells are often $30-60 \mu \mathrm{m}$ long. 
Table 2. Fatty acid profiles of Sediminitomix flava sp. nov. Mok-1-85 ${ }^{\top}$ and Flammeovirga aprica NBRC $15941^{\top}$, the closest phylogenetic neighbour

Data for Flammeovirga aprica NBRC $15941^{\mathrm{T}}$ are from Takahashi et al. (2006). Fatty acids amounting to $<1 \%$ of the total fatty acids are not shown.

\begin{tabular}{|c|c|c|}
\hline Fatty acid (\%) & Mok-1-85 & NBRC $15941^{T}$ \\
\hline \multicolumn{3}{|l|}{ Straight chain fatty acids: } \\
\hline $\mathrm{C}_{14: 0}$ & 5 & 8 \\
\hline $\mathrm{C}_{15: 0}$ & - & 1 \\
\hline $\mathrm{C}_{16: 0}$ & 6 & - \\
\hline \multicolumn{3}{|l|}{ Branched fatty acids: } \\
\hline $\mathrm{i}-\mathrm{C}_{13: 0}$ & - & 3 \\
\hline $\mathrm{i}-\mathrm{C}_{14: 0}$ & - & 2 \\
\hline $\mathrm{i}-\mathrm{C}_{15: 0}$ & 23 & 37 \\
\hline $\mathrm{a}-\mathrm{C}_{15: 0}$ & 1 & 1 \\
\hline \multicolumn{3}{|l|}{ Unsaturated fatty acids: } \\
\hline $\mathrm{C}_{16: 1} \omega 5 c$ & 21 & 2 \\
\hline $\mathrm{C}_{20: 4} \omega 6 c, 9 c, 12 c, 15 c$ & - & 24 \\
\hline \multicolumn{3}{|l|}{ Hydroxy fatty acids: } \\
\hline $\mathrm{C}_{15: 0} 3-\mathrm{OH}$ & - & 1 \\
\hline $\mathrm{i}-\mathrm{C}_{15: 0} 3-\mathrm{OH}$ & 2 & 4 \\
\hline $\mathrm{C}_{16: 0} 3-\mathrm{OH}$ & 18 & 9 \\
\hline $\mathrm{i}-\mathrm{C}_{17: 0} 3-\mathrm{OH}$ & 2 & - \\
\hline \multicolumn{3}{|l|}{ Summed features ${ }^{*}$ : } \\
\hline 2 & 2 & - \\
\hline 3 & 10 & - \\
\hline
\end{tabular}

${ }^{*}$ Summed feature $2, \mathrm{C}_{14: 0} 3-\mathrm{OH}$ and/or iso $\mathrm{I}-\mathrm{C}_{16: 1}$; summed feature 3 , iso- $\mathrm{C}_{15: 0} 2-\mathrm{OH}$ and/or $\mathrm{C}_{16: 1} \omega 7 c$.

the analysis of isoprenoid quinones. Strain Mok-1- $85^{\mathrm{T}}$ contained MK-7 as the only quinone.

Very low $16 \mathrm{~S}$ rRNA gene sequence similarities with any of the sequences available in DDBJ and the formation of a single clade with the genus Flammeovirga in the neighbourjoining and parsimony evolutionary trees indicated that strain Mok- $1-85^{\mathrm{T}}$ represents a novel genus in the family 'Flammeovirgaceae'. This phylogenetic conclusion was also supported by the fatty acid profile and other phenotypic characteristics of the novel strain (Table 1). Therefore, strain Mok- $1-85^{\mathrm{T}}$ is proposed as a member of a new genus and novel species, Sediminitomix flava gen. nov., sp. nov.

\section{Description of Sediminitomix gen. nov.}

Sediminitomix (Se.di.mi.ni.to'mix. L. n. sedimen -inis sediment; L. fem. n. tomix a thread; N.L. fem. n. Sediminitomix a thread isolated from sediment).

Gram-negative, non-motile, long rods (10-35 $\mu \mathrm{m}$ long and $0.5-0.7 \mu \mathrm{m}$ in width), chemo-organotrophic, catalase- and oxidase-positive. $\mathrm{NaCl}$ is required for growth. Major cellular fatty acids are iso- $\mathrm{C}_{15: 0}, \mathrm{C}_{16: 1} \omega 5 c$ and $\mathrm{C}_{16: 0} 3-\mathrm{OH}$. The main respiratory quinone is MK-7. Growth occurs at $15-40{ }^{\circ} \mathrm{C}$, negative result in the $\mathrm{O} / \mathrm{F}$ test for glucose. The
DNA G $+\mathrm{C}$ content is $38 \mathrm{~mol} \%$. The type species of the genus is Sediminitomix flava.

\section{Description of Sediminitomix flava sp. nov.}

Sediminitomix flava (fla.va. L. fem. adj. flava reddish yellow, the colour of the colonies).

Displays the following properties in addition to those given in the genus description. Colonies are large and orangecoloured with non-entire margins on HSMA plates. The colour of the colonies is due to saproxanthin. Growth occurs at $15-40{ }^{\circ} \mathrm{C}$ and is optimal at $25-30{ }^{\circ} \mathrm{C}$. Growth occurs at $2-4 \%(\mathrm{w} / \mathrm{v}) \mathrm{NaCl}$ and weakly at $1 \%(\mathrm{w} / \mathrm{v}) \mathrm{NaCl}$. Positive for the degradation of starch, gelatin, DNA, aesculin, alginate, Tweens 20,40 and 80 and for the production of $\mathrm{H}_{2} \mathrm{~S}$. Weakly positive result in tests for the degradation of agar. Negative in tests for the degradation of cellulose, CM-cellulose, chitin, carrageenan, urea and for indole production. Grows on $1 \%(\mathrm{w} / \mathrm{v})$ peptone agar prepared with artificial seawater, but does not grow on $1 \%$ $(\mathrm{w} / \mathrm{v})$ tryptic soya agar prepared with artificial seawater or on casein plates $[0.2 \%(\mathrm{w} / \mathrm{v})$ Bacto tryptone, $0.1 \%(\mathrm{w} / \mathrm{v})$ Bacto yeast extract, $1.2 \%(\mathrm{w} / \mathrm{v})$ casein and $1.5 \%(\mathrm{w} / \mathrm{v})$ agar dissolved in artificial seawater]. Sensitive to treatment at $55{ }^{\circ} \mathrm{C}$ for $10 \mathrm{~min}$. Nitrate is reduced to nitrite, but nitrite is not reduced to $\mathrm{N}_{2}$. Positive result in tests for $\beta$-glucosidase and $\beta$-galactosidase. Positive result for alkaline phosphatase, acid phosphatase, leucine arylamidase and valine arylamidase activities in the API ZYM test. Acids are produced from D-xylose, galactose, glucose, amygdalin, aesculin, cellobiose, starch, glycogen, gentiobiose and 2-ketogluconate in API $50 \mathrm{CH}$ tests. The DNA G $+\mathrm{C}$ content of the type strain is $38 \mathrm{~mol} \%$.

The type strain, Mok-1- $85^{\mathrm{T}}\left(=\mathrm{NBRC} 101625^{\mathrm{T}}=\mathrm{KCTC}\right.$ $12970^{\mathrm{T}}=$ CIP $109411^{\mathrm{T}}$ ), was isolated from marine sediment from Okinawa Island, Japan.

\section{Acknowledgements}

This work was supported by grant no. 04000182-0 from the New Energy and Industrial Technology Development organization (NEDO).

\section{References}

Altschul, S. F., Gish, W., Miller, W., Myers, E. W. \& Lipman, D. J. (1990). Basic local alignment search tool. J Mol Biol 215, 403-410.

Bäckhed, F., Ley, R. E., Sonnenburg, J. L., Peterson, D. A. \& Gordon, J. I. (2005). Host-bacterial mutualism in the human intestine. Science 307, 1915-1920.

Bernardet, J.-F., Nakagawa, Y. \& Holmes, B. (2002). Proposed minimal standards for describing new taxa of the family Flavobacteriaceae and emended description of the family. Int J Syst Evol Microbiol 52, 1049-1070.

Brosius, J., Palmer, M. L., Kennedy, P. J. \& Noller, H. F. (1978). Complete nucleotide sequence of a $16 \mathrm{~S}$ ribosomal RNA gene from Escherichia coli. Proc Natl Acad Sci U S A 75, 4801-4805. 
Cowan, S. T. \& Steel, K. J. (1993). Manual for the Identification of Medical Bacteria, 3rd edn. London: Cambridge University Press.

Fautz, E. \& Reichenbach, H. (1980). A simple test for flexirubin-type pigments. FEMS Microbiol Lett 8, 87-91.

Felsenstein, J. (1985). Confidence limits on phylogenies: an approach using the bootstrap. Evolution 39, 783-791.

Garrity, G. M. \& Holt, J. G. (2001). The road map to the Manual. In Bergey's Manual of Systematic Bacteriology, 2nd edn, vol. 1, pp. 119-166. Edited by D. R. Boone, R. W. Castenholz \& G. M. Garrity. New York: Springer.

Hiraishi, A., Shin, Y. K., Ueda, Y. \& Sugiyama, J. (1994). Automated sequencing of PCR-amplified 16S rDNA on 'Hydrolink' gels. J Microbiol Methods 19, 145-154.

Hudson, J. A., Schofield, K. M., Morgan, H. W. \& Daniel, R. M. (1989). Thermonema lapsum gen. nov., sp. nov., a thermophilic gliding bacterium. Int J Syst Bacteriol 39, 485-487.

Hugh, R. \& Leifson, E. (1953). The taxonomic significance of fermentative versus oxidative metabolism of carbohydrates by various Gram negative bacteria. J Bacteriol 66, 24-26.

Leser, T. D., Amenuvor, J. Z., Jensen, T. K., Lindecrona, R. H., Boye, M. \& Møller, K. (2002). Culture-independent analysis of gut bacteria: the pig gastrointestinal tract microbiota revisited. Appl Environ Microbiol 68, 673-690.

Lewin, R. A. (1970). Flexithrix dorotheae gen. et sp. nov. (Flexibacterales); and suggestions for reclassifying sheathed bacteria. Can J Microbiol 16, 511-515.

Lewin, R. A. \& Lounsbery, D. C. (1969). Isolation, cultivation and characterization of flexibacteria. J Gen Microbiol 58, 145-170.

Mesbah, M., Premachandran, U. \& Whitman, W. B. (1989). Precise measurement of the $\mathrm{G}+\mathrm{C}$ content of deoxyribonucleic acid by highperformance liquid chromatography. Int J Syst Bacteriol 39, 159-167.

Minamisawa, K. (1990). Division of rhizobitoxine-producing and hydrogen-uptake positive strains of Bradyrhizobium japonicum by nifDKE sequence divergence. Plant Cell Physiol 31, 81-89.

Nakagawa, Y. \& Yamasato, K. (1993). Phylogenetic diversity of the genus Cytophaga revealed by $16 \mathrm{~S}$ rRNA sequencing and menaquinone analysis. J Gen Microbiol 139, 1155-1161.
Nakagawa, Y., Hamana, K., Sakane, T. \& Yamasato, K. (1997). Reclassification of Cytophaga aprica (Lewin 1969) Reichenbach 1989 in Flammeovirga gen. nov., as Flammeovirga aprica comb. nov. and of Cytophaga diffluens (ex Stanier 1940; emend. Lewin 1969) Reichenbach 1989 in Persicobacter gen. nov. as Persicobacter diffluens comb. nov. Int J Syst Bacteriol 47, 220-223.

Perry, L. B. (1973). Gliding motility in some non-spreading flexibacteria. J Appl Bacteriol 36, 227-232.

Reichenbach, H. (1989). Genus I. Cytophaga, pp. 2015-2050. In Bergey's Manual of Systematic Bacteriology, vol. 3. Edited by J. T. Staley, M. P. Bryant, N. Pfennig \& J. G. Holt. Baltimore, MD: The Williams \& Wilkins Co.

Saitou, N. \& Nei, M. (1987). The neighbor-joining method: a new method for reconstructing phylogenetic trees. Mol Biol Evol 4, 406-425.

Schmidt, K., Connor, A. \& Britton, G. (1994). Analysis of pigments: carotenoids and related polyenes. In Chemical Methods in Prokaryotic Systematics, pp. 403-461. Edited by M. Goodfellow \& A. G. O’Donnell. West Sussex: John Wiley \& Sons.

Shewan, J. M. \& McMeekin, T. A. (1983). Taxonomy (and ecology) of Flavobacterium and related genera. Annu Rev Microbiol 37, 233-252.

Smibert, R. M. \& Krieg, N. R. (1981). General characterization. In Manual of Methods for General Bacteriology, pp. 409-443. Edited by P. Gerhardt, R. G. E. Murray, R. N. Costilow, E. W. Nester, W. A. Wood, N. R. Krieg \& G. B. Phillips. Washington, DC: American Society for Microbiology.

Swofford, D. L. (2000). PAUP*: Phylogenetic analysis using parsimony (*and other methods), version 4. Sunderland, MA: Sinauer Associates.

Takahashi, M., Suzuki, K.-I. \& Nakagawa, Y. (2006). Emendation of the genus Flammeovirga and Flammeovirga aprica with the proposal of Flammeovirga arenaria nom. rev., comb. nov., and Flammeovirga yaeyamensis sp. nov. Int J Syst Evol Microbiol 56, 2095-2100.

Thompson, J. D., Gibson, T. J., Plewniak, F., Jeanmougin, F. \& Higgins, D. G. (1997). The CLUSTAL_X windows interface: flexible strategies for multiple sequence alignment aided by quality analysis tools. Nucleic Acids Res 25, 4876-4882. 